Ger J Exerc Sport Res 2017 - 47:1

DOI 10.1007/s12662-017-0450-7

Received: 18 January 2017

Accepted: 1 February 2017

(c) Springer-Verlag Berlin Heidelberg 2017

CrossMark

\section{Ralf Brand' ' Claudia Voelcker-Rehage ${ }^{2}$}

'Department of Sports and Health Sciences, University of Potsdam, Potsdam, Germany

${ }^{2}$ Institute of Human Movement Science and Health, Technische Universität Chemnitz, Chemnitz, Germany

\title{
German Journal of Exercise and Sport Research
}

\section{Aims and scope}

This journal is the joint scientific publication of the Deutsche Vereinigung für Sportwissenschaft (German Association of Sports Science), Deutscher Olympischer Sportbund (German Olympic Sports Confederation) and Bundesinstitut für Sportwissenschaft (German Federal Institute of Sports Science). It pursues the central aims and scope of the preceding journal Sportwissenschaft, published from 1971 to 2016. The German Journal of Exercise and Sport Research stands for the German tradition of sport and exercise studies with its essential characteristic of combining science, the humanities, social and behavioral academic disciplines to arrive at a multifaceted description and theoretical understanding of sport and exercise. The journal publishes original articles (main articles, brief reports, reviews), which are subjected to a blind peer review process, as well as reviewed essays, commentaries and discussion papers on relevant topics related to sport and exercise research. Both English and German articles are accepted. The German Journal of Exercise and Sport Research is committed to scientific advancement on the international level. Bringing together excellent authors from the German-speaking and the international arena, the journal aims to become one of the foremost international and interdisciplinary sport and exercise journals. We invite you to contribute as an author and help us meet that ambitious goal!
Die Zeitschrift ist das gemeinsame wissenschaftliche Publikationsorgan der Deutschen Vereinigung für Sportwissenschaft (DVS), des Deutschen Olympischen Sportbundes (DOSB) und des Bundesinstitutes für Sportwissenschaft (BISp) und führt zentrale Anliegen der von 1971 bis 2016 als Sportwissenschaft publizierten Zeitschrift fort. Das German Journal of Exercise and Sport Research steht für die in Deutschland gewachsene Form von Sportwissenschaft, für die wesentlich ist, dass sich geisteswissenschaftliche, naturwissenschaftliche, sozialwissenschaftliche und verhaltenswissenschaftliche Fächer zugunsten einer angemessen facettenreichen Beschreibung und theoretischen Durchdringung des Phänomens Sport und Bewegung zusammenfügen. Die Zeitschrift publiziert im blind Peer-Review Verfahren wissenschaftliche Originalbeiträge (Hauptbeiträge, Kurzbeiträge, Literaturübersichten) sowie begutachtete Essays, Kommentare und Diskussionsbeiträge mit Bezug zu sportwissenschaftlich relevanten Themen. Akzeptiert werden sowohl auf englisch als auch auf deutsch verfasste Beiträge. Das German Journal of Exercise and Sport Research sieht sich explizit dem wissenschaftlichen Fortschritt im internationalen Maßstab verpflichtet. Gemeinsam mit exzellenten Autorinnen und Autoren aus dem deutschsprachigen und internationalen Raum soll die Zeitschrift $\mathrm{zu}$ einer international führenden interdisziplinären Fachzeitschrift für Sport und Bewegung weiterentwickelt werden. Wir laden Sie ein, als Autorin oder Autor gemeinsam mit uns an diesem herausfordernden Ziel zu arbeiten.

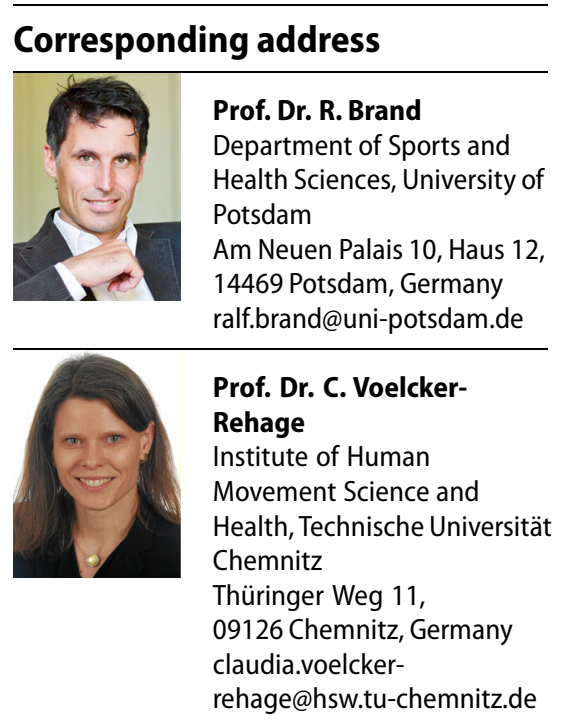

Conflict of interest. R. Brand and C. Voelcker-Rehage declare that they have no competing interests. 